\title{
The Critical Approach in Al-Muazana "In the Modern Equalization of Criticism" (A Criticism of Criticism)
}

\author{
Amal Abdullah Al-Huwairini \\ Department of Arabic Language, Princess Nourah Bint \\ Abdulrahman University, Riyadh, KSA
}

Received: 8/26/2021

Accepted: 9/20/2021

Publishe:10/24/2021

\begin{abstract}
The research was directed to the modern critical books that received the book "Al-Muazana bayna Abu Tammam and Al-Buhturi" by Abu Al-Qasim Al-Hassan bin Bishr for Al-Amidi (370 Ah) to answer the main question: what are the main features of criticism in Al-Muazana book in contemporary criticism books? The study aims to reveal the views on the critical approach of AlAmidi, and then trying to reconcile the opinions of contemporary critics that discussed the method of Al-Amidi in his book, one of them was the first book in which applied criticism appeared. One of contemporary critics' opinion was that it was characterized by investigating the opinions of the old critics about the Poetry of the Poets, a book in which objectivity was achieved in equalizing and neutrality. Contemporary critics almost agreed that Al-Amidi was characterized by planning his approach in the introduction to his book and its application. The most important results: AlAmidi explained the poetic thefts attributed to Al-Buhturi and Abu Tammam simultaneously. He explained the many poetries that Abu Tammam took from others with his many archives. Contemporary critics pointed out that Al-Amidi was not interested in the linguistic errors of poets, and he argued that there were many mistakes of ancient poets. Contemporary critics differed about Al-Amidi's intolerance of the poet Al-Buhturi and all his arguments.
\end{abstract}

Keywords: applied criticism, contemporary critics, old critics

Cite as: Al-Huwairini, A. A. (2021). The Critical Approach in Al-Muazana "In the Modern Equalization of Criticism" (A Criticism of Criticism) . Arab World English Journal for Translation \& Literary Studies 5 (4) 72-79. DOI: http://dx.doi.org/10.24093/awejtls/vol5no4.6 


\section{Introduction}

Thanks be to God, the Lord of the Worlds, and peace and prayers be upon the faithful leader and his companions, and those who followed them in charity, until the day of judgment. Now to the topic.

Contemporary authors carefully received the critical heritage and prepared scientific studies to plan critical approaches in the spirit of modern times. The research was based on the study of the book Al-Muazana bayna Abu Tammam wa Al-Buhturi (Equalizing between Abu Tammam and Al-Buhturi) (Al-Amidi, Al-Muazana bayna Abu Tammam and Al-Buhturi, n/a) by Abu Qasim Al-Hassan bin Bishr Al-Amidi (370 Ah) in The Modern equalization of criticism. The research was limited to some of the literature of modern criticism, and then limited the characteristics of the curriculum to the book Al-Muazana and some bibliography, and then applied by a selected model from the sections of the book.

The research's nature required recourse to the criticism of criticism, which is the third manifestation of critical knowledge coming after theoretical criticism and applied criticism. The origin of criticism (Metacritique) lies in the disclosure of the meaning in the literary text in the words of Abdul-Cairo Al-Jarjani. The criticism of criticism is the second criticism that is written on the first criticism of the literary text. The critique of criticism supplements and guides its path, and it is not necessary that the second critique be different or opposed to the first critique, it can be focus and rooting for the sources of knowledge of the first critique and the importance of the second critique is no less important than the function of the first critique (Murtad, 2010) of previous studies in the field of the subject of this research. Many of the critics studied the book $A l$ Muazana in a separate book or studied this book with studies on ancient criticism. However, the approach of this research is to collect the opinions of contemporary critics and reconcile them in order to get a clear picture of Al-Amidi critical approach of Al-Amidi in the book Al-Muazana.

The research aims to answer the following questions:

-What are the main features of criticism in Al-Muazana book in contemporary criticism books?

- How much do contemporary critics care for the book Al-Muazana?

\section{Literature Review}

The important previous studies are: Al-Faisal's study (1979): Issues and Critical Studies, Mandour's study (1996): Systematic Criticism of Arabs, Ismail's study (2012): Introduction of Arabic Applied Criticism, and Abu-Hamda's study (2013): Abu Al-Qasim and Almwazana Book. These studies included Al-Amidi's critical approach for other critics and views that have been presented, but the current study focused on Al-Amidi and the important characteristics of his approach.

\section{A Brief Overview of the Al-Amidi and the Importance of the "Al-Muazana" Book}

Abu Al-Qasim Al-Amidi: Al-Hasan bin Bishr bin Yahya Al-Amidi, Abu Al-Qasim: a literature scholar, a narrator, from the writers, wrote poetry. His origin is from Amed, his birth and death in Basra. Some of his books are Almutalif wa Al-Mukhtalaf (The identical and different) on 
the names of the poets, their surnames, titles and genealogies, and Al-Muazana bayna Abu Tammam wa Al-Buhturi (Equalizing between Abu Tammam and Al-Buhturi), Maeani sheer AlBuhturi (Meaning of Al-Buhturi's poem), Alkhas wa Al-Mushtarak (The private and common) on the meanings of poetry, Nathr Al-Manzum (Prose of the Poems), Tabayin ghalat Qudamat bin Jaefar fi kitab naqd alsheer (Explaining Qudamat Bin Jaefar's Mistake in Criticism of Poems Book), Tafdil sheer eimri alqayis ala aljahiliiyn (Preferring Eimri Alqayis' Poems over the PreIslamics Poems), and kitab faalto wa 'afaalto ( The Book of I Did and I made You Do).

He is the author of the book Al-Mwazana Bayn Altaiyin, was well understood, well informed and novel, quick to understand, was the writer of justice in Basra, and he has good poetry and a breadth of literature (Al-Hamawi, 1991).

In this book, the author Abu al- Qasim Al-Hasan Ibn Bishr Al-Amidi begins by mentioning the disadvantages of the two poets: Abu Tammam and Al-Buhturi, and concludes by mentioning their advantages. He mentions part of Abu Tammam's thefts, his referrals, his mistakes, and the disadvantages of Al-Buhturi, by what he has taken from the meanings of Abu Tammam, and other mistakes in some of its meanings.

Then he equates their poetry between a poem and a poem if they agree in meter, rhyme, and syntax of the rhyme. Then between a sense and a meaning, for their virtues appear as they are revealed. After this, the author mentions the meaning of each one of them that he has followed and that of its owner that he has not followed. The author assigns a special section to what happened in their poetry of the parable, simile and a section to the proverbs, and the author follows this with an abstract test of their poetry, and he follows this by selecting from their poetry.

Literary equalizing increased in the fourth century AH, including the book Al-Muazana by Al-Amidi (Al-Harkani, 2013), and some critics believe that Al-Muazana is the first critical book on the equalizing in Arabic criticism, according to the approach mentioned by Al-Amidi in the introduction of his book.

The importance of the book lies in the fact that it compares two great poets, and it compares the development through innovation which is represented by Abu Tammam and his team, and the development by holding onto the classical poetry represented by Al-Buhturi and his team. (Al-Qit, 1982)

\section{The Most Important Contemporary Critics' Opinions on Al-Muazana Book}

The critics agreed on the quality of the approach of the critical Al-Amidi in book he presented, he mentioned in the introduction to his book the approach he will follow in his book; he will deal with the poetry of Abu Tammam and the poetry of Al-Buhturi, and he will present the opinions of the supporters and opponents of the two impartially, without favoring one over the other, and he ended his book without making a final judgment on the preference of one poet over the other. He will present the statements in the pro and con arguments of the two poets and only comment on his opinion in short words such as saying, "this is the right thing to do" and with the 
explanation and mention of the arguments (Al-Faisal, 1979; Al-Qit, 1982; Masabih, 2009; AlHarkani, 2013; Mandour, 1996).

One of the features of the approach of Al-Amidi is the investigation in which the evidence is presented and commented upon, and the opinions of ancient critics and contemporaries are mentioned, without mentioning the names of some of them, except those who were known as Ibn Al-Mu'taz, and Al-Amidi an objective analysis (Al-Faisal, 1979; Mandour, 1996).

Al-Amidi fully set out his critical viewsn an orderly and reasoned manner (Al-Qit, 1982). One of the critics justified Al-Amidi's ingenuity in equalizing and his objectivity to the fact that he was a judge who separated the opponents (Abu-Hamda, 2013).

Contemporary critics praise Al-Amidi for discussing a critical issue that has been talked about in his reign, namely poetic thefts, and then Al-Amidi noticed that taking the two poets from each other is possible to coincide with them, as he explains the many thefts which are attributed to Abu Tammam in a great deal of preservation (Masabih, 2009; Mandour, 1996).

Al-Amidi also explained in his introduction that he will equalize between the line and the two lines that are similar in meter and rhyme without the full poems, which some critics take on it (Abu-Hamda, 2013).

Critics praised him Al-Amidi approach for his keenness to investigate the right thing and verifying the validity of the poems of Al-Buhturi and Abu Tammam he lists (Al-Faisal, 1979).

Critics also agreed, or almost agreed, that Al-Amidi was the first to use applied criticism, and applied criticism is the consequence of theoretical criticism, which provides him with the standards and tools of textual analysis and interpretation, which is the purpose of criticism, to serve the text and reveal its eloquence (Murtad, 2010). The applied criticism, which appeared clearly in

Al-Muazana book, explained the books of the ancient poets and critics, then "work like we do now, when we want to study any of the issues, we collect the books that have been put in them, we decide what to accept from them and adopt what we consider as a final profit, then we cheque what he sees wrong, and show what has been left in the shadows. (Mandour, 1996, p. $105)$.

\section{Al-Amidi's Tools in Criticism}

His strongest tools are literary knowledge, criticism, and taste; he is a poet and a writer, and the exact attitude for Al-Amidi is the attitude to the issue of the old and the new in literature; it was reasonable and fair, and the justice in critical governance means safety from dispensable intolerance of argument. His literary taste also flowed into his book. His acumen was reflected in the importance of formulation in literature (Abu-Hamda, 2013; Mandour, 1996). His critical taste was manifested in his impressionistic views scattered among objective opinions. 
Al-Amidi used his grammatical and linguistic knowledge as a criterion to judge between poets (Masabih, 2009). Al-Amidi's historical culture was also evident in his interpretation of phenomena and his understanding of the sequence between different doctrines, as well as in his presentation and discussion of the views of ancient critics such as Al-Suli and Ibn Al-Mu'taz. (AlQit, 1982).

The critical thinking of Al-Amidi was manifested in his view of poetry, in terms of the relationship between poetry and scholarship, as he believes that poetry does not equal scholarship, in response to the supporters of Abu Tammam who presented him as a scholar. He also believes that the poetry of scholars has a lower status than the poetry of poets. Al-Amid also said that if scholars progress in poetry, they will precede poets, and there is no need to criticize poetry (Mandour, 1996).

Al-Amidi then examined the relation between poetry and philosophy and found that poetry differs from philosophy, and even mocks at the introducing philosophy into poetry, and who says philosophy is called a philosopher. Therefore, most contemporary critics agreed on the soundness of Al-Amidi's critical thinking, and literary taste when he made the status of poetry incomparable to scholarship and philosophy (Abu-Hamda, 2013; Mandour, 1996).

Al-Qit talks about the appearance of controversy and philosophy in Al-Muazana, saying: "Although controversy and philosophy appeared in the introduction to the book 'Al-Muazana', they were not only highlighted in the introduction in a way that did not represent the view of AlAmidi.” (Al-Qit, 1982, p. 36)

\section{Opinions in which Critics Disagreed on the Al-Amidi Approach}

Many ancient critics like Al-Hamawi-(Al-Hamawi, 1991) and contemporaries described the intolerance of the poet Al-Buhturi against Abu Tammam. Some disagreed with them and denied intolerance of Al-Amidi and described those who are intolerant of him as being late when taste is corrupted and the overpower of workmanship and mannerism (Mandour, 1996).

A contemporary critic explains the intolerance of Al-Amidi against Abu Tammam that his intolerance is not a consistent approach or attitude but was due to the disturbance of his attitude on the poets (Al-Ghamdi, 2008). A contemporary critic explains Al-Amidi's intolerance against Abu Tammam by saying that his intolerance is not a consistent approach or attitude but was due to the disturbance of his attitude towards poets (Al-Qit, 1982).

\section{The Applied Study on three Sections of the Al-Muazana Book}

Al-Amidi began the conversation on the topic (beginnings by mention stopping by the home) with a brief introduction, "He will compare the two verses or the two pieces if they match in terms of meter, rhyme, and declension, but this is hardly consistent with matching the meanings to which the destination is directed" (Al-Amidi, n/a, p. 384). 
This brief introduction illustrated his approach by making do with a verse that is attuned to meter, rhyme and complete poems, and the argument may be that he will deal with stopping by the home, which is the introduction to the poems, and will not need the rest of the poem's verses.

Al-Amidi was able to make fairness and justice with the help of God, and justice has been achieved in his equalization. He was also good at introducing verses by one or two verses and then commenting on them by saying, "This is a good, acceptable beginning" (Al-Amidi, n/a, p. 385) and explaining the words defined by the names included and what was incomprehensible. This is the applied approach that contemporary critics praised, and they considered Al-Amidi to be the first to use it.

He introduces a verse of Abu Tammam and then a verse of Al-Buhturi, commenting on them by Mazhar Al-Hassan, and insists precisely on the bad, like saying: "This is a good word, and it means not good." (Al-Amidi, n/a, p. 387) When Al-Amidi was cited by the saying of Abu Tammam:

"Stopping by the home does not stop your longing, so get down"1

"And wet your longing with the tears to get wet"

Al-Amidi commented on "good meaning and quoted the verse of the poet Al'asam Al-Bahili near meaning" (Al-Faisal, 1979, p. 141), which means his digression and the mention of poems other than Abu Tammam and Al-Buhturi, and this is his approach in the rest of the book.

The literary culture of Al-Amidi and its investigative approach and its development of Arab customs, such as the poets stopping the ruins of their riding animals without going down and passing through the ruins if they are on the exposed road, although they are not on the exposed road, the poet said: (zigzag, crook ) and quotes his opinion about the poetry of the ancient poets.

Al-Amidi then gives another idea about stopping because of standing on ruins from the generosity of the covenant and the good faithfulness and ignore home when passing through it from the villainy and the bad covenant.

He mentions the idea of stopping at home for a reason other than handing over the home and mentioning loved ones, so the goal of stopping can be to rest the bear and get that idea out of the way of starting to stand. Al-Amidi did not fault with the melody into which the two poets may fall, and his argument is that the late people are hardly spared melody, and in their poems, it is too much.

Regarding the comments of Al-Amidi in this section "This is a good meaning, and this is a beautiful sense, and this is a good word, and it means not good, and it is a good beginning, and this beginning is not good to say it (who $)^{3}$, because it is not a beautiful word, it is not famous," he said.

One of the views of the contemporary critics in the critical approach of Al-Amidi was that he did not prefer one poet over the other, and at the end of this section, he said, "This is what they 
started by mentioning standing, and making them equal, for the ingenuity of the first two verses of Al-Buhturi and this is what he mentioned in the introduction to his book" (Al-Amidi, n/a, p. 394).

In the section of compliment at home:

The verses quoted a single verse followed by a comment such as, "This first hemistich is very good and brilliant, and the inability of the verse is also very good." (Al-Amidi, n/a, p. 384)

In a verse he said, "Greet the quarter of Salma with a ladder...." (Al-Amidi, n/a, p. 385), “This isn't a good beginning, because it comes with naturalization in three words, but it becomes better when it is in two words, and it comes like this in people's poems, and the bad one does not come to it" (Al-Amidi, n/a, p. 387).

Here is a witness to contemporary critics' evidence of Al-Amidi's approach of demonstrating the judgment with an explanation coming from literary and critical culture.

In the section of the beginning by mentioning the exemption home of centuries and time.

In his objective equalizing, he replied on Abu Tammam's verse:

"Centuries wiped out Mawia's home"4

"Is the destiny of writing the poems will be wiped or stolen?"5

Al-Buhturi said: (Al-Amidi, n/a, p. 394)

"Is this a leftover of home or lines of book?"6

"Its happiness has been wiped through centuries"7

Al-Amidi commented critically, "This house is more brilliant than Abu Tammam's verse, and it's the finest structure, the most elegant, and it's one of the rare and strange beginnings, similar to the words of first ones and it has poets of Abu Tammam" (Al-Amidi, n/a, p. 394), also he has equated the two verses in a critical way and with deep thinking in literary meanings, which indicates a culture and the capacity of scholarship, and thus a distinct critical approach that became an approach for the critics who followed him (Al-Amidi, n/a).

\section{Conclusion}

This research was directed to the modern criticism books that received the book $A l$ Muazana bayna Abu Tammam wa Al-Buhturi (Equalizing between Abu Tammam and Al-Buhturi) by Al-Amidi with the aim of revealing their views on his critical approach, and then trying to reconcile their opinions, based on the criticism-criticism approach, and by answering a major question: what are the most important features of criticism in the book Al-Muazana in the books of contemporary criticism?

The research concluded that the research reached the agreement of contemporary critics that Al-Amidi excelled in presenting the views of old critics and his contemporaries, and their differences about Al-Amidi's fanaticism of Al-Buhturi and his arguments, and that the AlMuazana book represents a good beginning in applied criticism that presents the texts and their critical judgments objectively. 


\section{Endnotes}

1. In Arabic: "laysa alwuqufu ykffu shwqaka fanzili".

2. In Arabic: "wablul ghalilka bialmadamiei yublali".

3. In Arabic: "allaayiyna".

4. In Arabic: "laqad 'akhadhat min dari mawiata alhuqbu".

5. In Arabic: "'anuhlu almaghani lilbalaa hia 'am nahbu?".

6. In Arabic: "'arusumu darin 'am sturu kytabi".

7. In Arabic: "darasat bashashatuha 'ala alahqabi".-

\section{About the Author:}

Amal Abdullah Al-Huwairini is an Assistant Prof. of General Specialization, Arabic Language, Specialization, Arabic Literature and Criticism. Bachelor of Arts from Princess Nourah Bint Abdulrahman University at Department of Arabic Language. Amal has published some researches as: "Social Attitude in the Articles of the Writer Jawaher Al-Sheikh". ORCID ID: https://orcid.org/0000-0002-1591-0598.

\section{References}

Abu-Hamda, M. (2013). Abu al-Qasim and Almwazana book ( $1^{\text {st }}$ ed.). Amman: Dar Emad.

Al-Amidi. (n/a). Al-Muazana bayna Abu Tammam and Al-Buhturi. n/a: Mohammed Mohi eddin Abdel Hamid.

Al-Amidi. (n/a). Al-Muazana bayna Abu Tammam and Al-Buhturi. n/a: Mohammed Mohi eddin Abdel Hamid.

Al-Faisal, A. (1979). Issues and critical studies (1 ${ }^{\text {st }}$ ed.). Cairo, Egypt: Dar Ehiaa Alkutub Alarabia. Al-Ghamdi, M. (2008). Talaqiy sheer 'abi tamaam einda alarab. Al-Baha: Alnadi Aladabi.

Al-Hamawi, Y. (1991). Dictionary of Writers (1 ${ }^{\text {st }}$ ed.). Beirut: Scientific Book Home.

Al-Hamawi, Y. (1991). Dictionary of Writers (1 ${ }^{\text {st }}$ ed.). Beirut: Scientific Book Home.

Al-Harkani, T. (2013). Criticism of literary criticism throughout Arab history (1 ${ }^{\text {st }}$ ed.). Baghdad: Dar Adnan.

Al-Harkani, T. (2013). Criticism of literary criticism throughout Arab history (1 ${ }^{\text {st }}$ ed.). Baghdad: Dar Adnan.

Al-Qit, A. (1982). The concept of poetry in the Arabs as depicted in Al-Mwazana book (1 ${ }^{\text {st }}$ ed.). (A. Al-Qit, Trans.) Cairo: Dar Al-Maarif.

Mandour, M. (1996). systematic criticism of Arabs (n/a ed.). Cairo, Egypt: Dar Alnahda.

Masabih, M. (2009, October 29). Nashiri electronic publishing home. Retrieved August 20, 2021, from nashiri: https://bit.ly/3k5uEqO

Murtad, A. M. (2010). the theory of criticism (1 ${ }^{\text {st }}$ ed.). Bouzarea, Algeria: Dar Huma press.

Murtadat, A. M. (2010). the theory of criticism (1 ${ }^{\text {st }}$ ed.). Bouzarea, Algeria: Dar Huma press.

Arab World English Journal for Translation \& Literary Studies 